\title{
Development of an Attitude Scale for Cancer Screening
}

\author{
(1) Elif Nur YILDIRIM ÖZTÜRK'1, (1) Mehmet UYAR², (D) Tahir Kemal ŞAHIN², \\ ${ }^{1}$ Konya Akşehir County Health Department, Konya-Turkey \\ ${ }^{2}$ Department of Public Health, Necmettin Erbakan University Meram Medical Faculty, Konya-Turkey
}

\section{OBJECTIVE}

This study aims to develop a scale to measure people's attitudes towards cancer screening and conduct a pilot study and validity-reliability study of the developed scale.

\section{METHODS}

This methodological study was conducted on 334 voluntary male and female relatives of patient who were between 30-70 years of age and attend family health centers at Meram district of Konya province. A sociodemographic form and a candidate scale were used for data collection. Data analysis was performed in a computer setting.

\section{RESULTS}

The study group of 334 participants consisted of $50 \%$ males and $50 \%$ females, and the mean age was $42.93 \pm 9.60$ years. Four items with item score-scale score correlation less than \pm 0.200 were excluded from the 28-item candidate scale. Cronbach's alpha coefficient of the 24-item scale was calculated as 0.95. Face and content validity of the scale was evaluated with two different groups. Factor analysis that was used to assess the construct validity of the one-dimensional 24-item scale determined that explained the variance ratio was $52.62 \%$.

\section{CONCLUSION}

As a result of our study, a new five-point Likert scale called "Attitude Scale for Cancer Screening" has been developed. Validity and reliability studies of the scale suggest that the scale is suitable for use in our society.

Keywords: Attitude; cancer screening; early diagnosis; scale development. Copyright $\odot$ 2020, Turkish Society for Radiation Oncology

\section{Introduction}

Cancer is among the top ten causes of death worldwide.[1] According to global cancer data published in September 2018, there were 18.1 million new cancer diagnoses and 9.6 million deaths caused by cancer.[2] In Turkey, "Causes of Death Statistics" published in April 2018 reported that $39.7 \%$ of deaths arose from circulatory system diseases, $19.6 \%$ malignant and benign neoplasms, and $12 \%$ respiratory system diseases.[3]

Early diagnosis and treatment are possible in some forms of cancer, a public health concern faced by both the world and our country. Early diagnosis and treatment may increase the patient's life quality and prevent cancer-related death. These reasons increase the significance of cancer screening.[4] Various institutions and textbooks reported that screening must have made for breast, colorectal, cervix, endometrium, lung, prostate, liver, stomach, oral, and pharyngeal cancers. [5-10] The World Health Organization recommends screening for breast, colorectal, and cervix cancer.[10] The "National Cancer Screening Program" in Turkey consists 
of screening for three types of cancer, including breast cancer, cervix cancer, and colorectal cancer.[11]

To observe the benefits of community-based cancer screening programs, such as reducing cancer-specific mortality rate, cancer-specific fatality rate, and cancer-specific complication/sequelae rate, preventing recurrence and metastasis, and increasing patients' life quality, the individuals of the community must participate in screening programs.[12] To predict the behavior of individuals participating in or not participating in screening, attitudes need to be measured reliably.[13]

In a study conducted by Tekpinar et al.[14] on 752 people who applied to the family health center, the findings showed that $23.4 \%$ of the participants had cancer screening tests at least once before.In a study conducted with 380 people in Bingöl, $3 \%$ of women had mammography, $5.9 \%$ had a pap-smear test, $4.5 \%$ of women and men had a fecal occult blood test and 1.8\% had a colonoscopy.[15] In a study conducted with 562 people in a family health center in Aydın, $7.7 \%$ of the participants had a fecal occult blood test, $3.6 \%$ of sigmoidoscopy and $5.4 \%$ of colonoscopy.[16] In a study conducted with 152 women in İzmir, 44.1\% of women have never had mammography, $44.1 \%$ have never had a pap-smear test and 9.9\% had a colonoscopy.[17]

When the national and international literature is examined, it is observed that there are scales developed for breast, cervical and colon cancer screenings through models, such as the health belief model, but a scale that would measure the general attitude towards cancer screenings is not available in the literature. It is important for the researchers to measure society's general attitude towards cancer screening with a standard scale for cancer screenings that are currently being applied and are likely to be added recently. By accurately measuring the mentioned attitude, effective interventions can be planned for groups that show both positive and negative attitudes, and cancer screening rates can be increased.

This study aims to develop a scale to measure the attitude towards cancer screening, conduct a pilot application and validity-reliability study of the developed scale, and determine the characteristics that may be related to the scale score.

\section{Materials and Methods}

This study is a methodological type scale-development, validity, and reliability study. The study obtains ethical approval from Necmettin Erbakan University Meram
Faculty of Medicine Ethics Committee (No: 2019/1733; Date: 15.02.2019).

Within the scope of this study, 334 male and female patient relatives aged 30-70 years who provided oral and written consent to participate in this study and who did not have cognitive, visual, and orthopedic disabilities preventing them from completing the forms were included. The reason that patients' relatives were preferred instead of patients is that patients might be more prone to health care use. Bias was tried to be avoided by including patients' relatives instead of patients. Age range was specified as 30-70 since the minimum age requirement for the "National Cancer Screening Program" was 30 (for cervix cancer) and the maximum age requirement was 70 (for colorectal cancer). The national values of the relevant society can be taken as a basis for using the scale in other societies. The literature indicates that 50 people are very inadequate, 100 inadequate, 200 moderately adequate, 300 adequate, and 500 people are very adequate for conducting scale-development, validity and reliability studies.[18] In pilot studies conducted before the validity and reliability studies, 50 participants are recommended when the number of items on the scale is less than 30 and two or three times more participants are recommended when there are 30 or more items. [19] In this regard, at least 50 participants are intended for the pilot study and at least 300 for the validity-reliability study. Care is taken to ensure there was an equal number of male and female participants so that the scale could be reliably used in both men and women. This study was conducted at the family health centers of the Meram district of Konya province between the dates of $01 / 03 / 2019-01 / 06 / 2019$. The reason for this study to be conducted in family health centers is to want to reach society easily.

The data collection form used in this study was developed after reviewing the literature related to scaledevelopment and cancer screening. The data collection form consisted of two sections, including a 15-question sociodemographic data form and a 28 -item candidate scale. The five-point Likert type candidate scale includes 16 negative and 12 positive statements. The candidate scale required answers on a scale of 1-5 (5: completely agree, 4 : partially agree, 3 : neither agree nor disagree, 2 : partially disagree, 1 : completely disagree). The 28 items of the candidate scale were designed to accommodate a one-dimensional scale. In the data collection process, participants completed the forms by themselves under supervision. Each form was completed in about 20 minutes. 


\section{Statistical Analysis}

Data input, statistical analysis, and report writing were performed in computer settings. Numerical data were expressed as $\overline{\mathrm{x}} \pm$ sd, median ( $\min -\mathrm{max}$ ) values, while categorical data were expressed as frequency distributions (n) and percentages (\%). In the reliability study of the candidate scale, item score-scale score correlation coefficient, item analysis based on the difference of $27 \%$ sub-upper group means, Split-Half reliability method and Cronbach's alpha coefficient are used. For the validity study of the candidate scale, face validity, scope validity, and explanatory factor analysis for construct validity were performed.

After performing validity-reliability studies of the scale, when the relations between score and certain char- acteristics of the participants provided normality criteria, they were compared using Independent-samples t-test, one-way analysis of variance, and Pearson's correlation coefficient; when they do not provide normality criteria, nonparametric equivalents of the same tests are used for comparison. Values-based on statistical analysis are presented in Table 1 and the stages of the scale's development process are demonstrated in Figure 1.

\section{Results}

\section{Sociodemographic Characteristics}

Mean participant age was $42.93 \pm 9.60$ years and the median age was 42 (30-70). The 334 people within the

Table 1. Statistical values-based on analysis

\section{Statistical Method}

Item-Scale Correlation Coefficients

Spearman-Brown Split Half Coefficient

Guttman Split Half Coefficient

Cronbach's Alpha Coefficient

Content Validity

Kaiser-Meyer-Olkin (KMO) Test for Sampling Adequacy

Bartlett's Test for Sphericity

Factor Loading

Pearson and Spearman Correlation Coefficients

\section{Acceptance Level}

$> \pm 0.200[19,20,21]$

$>0.70[19,21]$

$>0.70[19,21]$

$>0.90$ Excellent

0.80-0.90 Good

0.70-0.80 Acceptable

0.60-0.70 Moderate

0.50-0.60 Weak

$<0.50$ Unacceptable [22]

It is recommended that the expert group to be consulted should be between 5 and 40 people. It is recommended that the expert group consist of people who have sufficient qualifications and knowledge in the subject area, who under stand the importance of the study, and are able to allocate sufficient time.[23,24]

$>0.90$ Excellent

$0.80-0.90$ Good

0.70-0.80 Acceptable

0.60-0.70 Moderate

$0.50-0.60$ Weak

$<0.50$ Unacceptable $[13,22]$

The test is based on Chi-square statistics. P-value less than 0.05 indicates the relevant data are adequate for factor analysis.[13]

0.30 should be accepted as the smallest factor load in ex planatory factor analysis.[21,23,25,26]

0.00-0.19 Negligible

0.20-0.39 Weak correlation

0.40-0.69 Moderate correlation

0.70-0.89 Strong correlation

$0.90-1.00$ Very strong correlation

Positive correlation coefficients indicate that both variables increase or decrease together, while negative correlation coefficients indicate that as one variable increases, so the other decreases, and vice versa.[23] $<0.05$ 


\begin{tabular}{|c|c|c|c|}
\hline \multirow[t]{2}{*}{ Table 2.} & \multicolumn{3}{|c|}{$\begin{array}{l}\text { Sociodemographic characteristics of the re- } \\
\text { search participants }\end{array}$} \\
\hline & \multicolumn{2}{|l|}{ Characteristics } & n (\%) \\
\hline \multirow{2}{*}{\multicolumn{2}{|c|}{ Gender }} & Female & $167(50.0)$ \\
\hline & & Male & $167(50.0)$ \\
\hline \multirow{3}{*}{\multicolumn{2}{|c|}{ Marital status }} & Married & $284(85.0)$ \\
\hline & & Single & $27(8.1)$ \\
\hline & & Divorced/Widow & $23(6.9)$ \\
\hline \multirow{6}{*}{\multicolumn{2}{|c|}{ Education level }} & Elementary & $41(12.3)$ \\
\hline & & Middle school & $31(9.3)$ \\
\hline & & High school & $53(15.9)$ \\
\hline & & University & 139 (41.6) \\
\hline & & Master's & \\
\hline & & degree/Doctorate & $70(21.0)$ \\
\hline \multirow{2}{*}{\multicolumn{2}{|c|}{ Smoking at any period of life }} & Yes & $194(58.1)$ \\
\hline & & No & $140(41.9)$ \\
\hline \multirow{2}{*}{\multicolumn{2}{|c|}{ Regularly exercise }} & Yes & $130(38.9)$ \\
\hline & & No & $204(61.1)$ \\
\hline \multirow{2}{*}{\multicolumn{2}{|c|}{ Healthy eating habits }} & Yes & $189(56.6)$ \\
\hline & & No & $145(43.4)$ \\
\hline \multirow{2}{*}{\multicolumn{2}{|c|}{ Presence of chronic disease }} & Yes & $86(25.7)$ \\
\hline & & No & $248(74.3)$ \\
\hline \multirow{2}{*}{\multicolumn{2}{|c|}{ Presence of cancer }} & Yes & $10(3.0)$ \\
\hline & & No & $323(97.0)$ \\
\hline \multirow{2}{*}{\multicolumn{2}{|c|}{ Cancer in first-degree relatives }} & Yes & $75(22.5)$ \\
\hline & & No & $259(77.5)$ \\
\hline \multirow{2}{*}{\multicolumn{2}{|c|}{ Previously screened for cancer }} & Yes & $71(21.3)$ \\
\hline & & No & $262(78.7)$ \\
\hline
\end{tabular}

scope of this study consisted of 167 (50\%) females and $167(50 \%)$ males. Characteristics of the participants are presented in Table 2.

\section{Reliability of the Scale}

Item score-scale score correlation, 27\% sub-upper group analysis, Cronbach's alpha coefficient, Spearman-Brown and Guttman Split-Half coefficients for the 28 -item candidate scale are presented in Table 3.

\section{Construct Validity of the Scale}

Before performing the explanatory factor analysis for construct validity, the Kaiser-Meyer-Olkin (KMO) test for sampling adequacy and Bartlett's test for sphericity were conducted to determine whether or not the study group was suitable for factor analysis. The KMO value of the study group was calculated as 0.96 . Bartlett's test for sphericity yielded significant results (Chi-square $=$ 6764.30; $\mathrm{p}<0.001$ ).

Explanatory factor analysis was used to determine the construct validity of the candidate form. Since the items of the 28 -item candidate scale were initially com- posed to accommodate a one-dimensional design in the writing stage, this was assessed with factor analysis. Factor loadings according to the "Principal Component Analysis" factor analysis method of the one-dimensional scale, which was reduced to 24 items as a result of reliability analyses are presented in Table 4 .

\section{Features of the Developed "Attitude Scale for Cancer Screening"}

The five-point Likert-type scale consisted of 24 items and one dimension. The items were answered on a scale from 5 to 1 [5: completely agree, 4: partially agree, 3: neither agree nor disagree, 2: partially disagree, 1 : completely disagree].

The scale is suitable for use in males and females between 30-70 years of age, who are at least literate and do not have cognitive, visual, or orthopedic disabilities, impeding them from completing the form.

Application of the scale is as follows: The participant reads and answers the scale items by themselves while under supervision by the researcher. The scale can be applied with a proper sampling and application method in any situation where it is needed to measure attitude towards cancer screening.

The minimum score of the scale is 24 and the maximum score is 120 . Since the scale is an attitude scale, no specific cut-off point was established. Scores near 24 indicate negative attitude, while scores near 120 indicate a positive attitude towards cancer screening. When calculating scores, 13 items with statements of negative meaning (Items 9, 12, 14-24) should be inversely coded. The order of the items is not important. The researchers may use a mixed order for the items.

\section{Attitude Scale for Cancer Screening-Short Form}

Given that researchers may require a shorter form during conducting their studies, a short form consisting of 15 items from the original 24-item Attitude Scale for Cancer Screening was also developed.

The short form is as follows: The lowest score that can be obtained from the scale is 15 and the highest score is 75 . Since the scale is an attitude scale, there is no specific cut-off point. Scores closer to 15 indicate a negative attitude towards cancer screening, while scores closer to 75 indicate a positive attitude. When calculating scores, 6 items with "reverse" statements of negative meaning, which are indicated in Table 4 should be inversely coded. The order of the items is not important. The researchers may use a mixed order for the items. The statistical characteristics of the short form are presented in Table 5 . 
Review of scales and research related to attitudes towards cancer screening in national and international literature.

1

Formation of an 88-item item pool for the candidate scale.

2

Formation of a 35-item draft form by removing redundant items considered to have same or similar meaning from the item pool.

3

Review of the 35 -item form by a group of 10 public health research assistants for face validity.

4

Making recommended corrections after review of face validity

5

Submitting the form to a group of 17 experts for content validity (The team consists of four public health specialists, four medical oncologists, three general surgeons, three family medicine specialists, one medical doctor who woprks in early cancer diagnosis and screening centers (KETEM in Turkey), one gastroenterologist and one faculty member who works in the recreation department and gives courses about scale development and adaptation.)

Content validity corrections based on recommendations and reducing the number of items to 29

7

Pilot study with 39 women and 39 men aged 30-70 in the field (It is tried that the group in which the pilot application was made and the group in which the scale would be used would be similar.)

8

After the pilot study, obtaining a 28-item candidate scale by editing the form and removing 1 item that causes difficulty in understanding by people

9

Validity and reliability field study of the candidate scale conducted on 334 people

10

Fig. 1. Qualitative and quantitative process of the scale.

\section{Variables Affecting the Scale Score}

Mean "Attitude Scale for Cancer Screening" score of the study group, which consisted of 167 males and $167 \mathrm{fe}-$ males was 60.51 \pm 27.80 . Median score was 51 (24-120). Welch ANOVA test showed that as education level increased, attitudes became more negative and scale scores significantly decreased. Post-hoc Tamhane's T2 test determined that difference stemmed from elementary-university, elementary-master/doctorate, middle school-university, middle school-master/doctorate, and high school-master/doctorate groups. Participants who smoked at any point in their life had significantly higher scores. Variables that affected scale scores are presented in Table 6.

\section{Discussion}

\section{Determining Reliability with Cronbach's Alpha Co- efficient}

The most commonly used method to test the reliability of a scale is Cronbach's alpha coefficient. The Alpha coefficient method, developed by Cronbach in 1951, 
Table 3. Item score-scale score correlations of the candidate scale

\begin{tabular}{|c|c|c|c|}
\hline Scale Items & $\begin{array}{l}\text { Item score-Scale } \\
\text { score Correlation }\end{array}$ & $\begin{array}{l}\text { Cronbach's alpha } \\
\text { after item removal }\end{array}$ & $\begin{array}{l}\text { Final status of } \\
\text { the item }\end{array}$ \\
\hline Item 1 & 0.837 & 0.930 & Remained \\
\hline Item 2 & 0.738 & 0.932 & Remained \\
\hline Item 3 & 0.012 & 0.940 & Removed \\
\hline Item 4 & 0.795 & 0.931 & Remained \\
\hline Item 5 & 0.801 & 0.931 & Remained \\
\hline Item 6 & 0.822 & 0.930 & Remained \\
\hline Item 7 & 0.811 & 0.931 & Remained \\
\hline Item 8 & 0.708 & 0.932 & Remained \\
\hline Item 9 & 0.785 & 0.931 & Remained \\
\hline Item 10 & 0.372 & 0.936 & Remained \\
\hline Item 11 & 0.850 & 0.930 & Remained \\
\hline Item 12 & -0.140 & 0.942 & Removed \\
\hline Item 13 & 0.548 & 0.934 & Remained \\
\hline Item 14 & -0.193 & 0.942 & Removed \\
\hline Item 15 & 0.547 & 0.934 & Remained \\
\hline Item 16 & 0.473 & 0.935 & Remained \\
\hline Item 17 & 0.362 & 0.936 & Remained \\
\hline Item 18 & 0.171 & 0.939 & Removed \\
\hline Item 19 & 0.500 & 0.935 & Remained \\
\hline Item 20 & 0.534 & 0.934 & Remained \\
\hline Item 21 & 0.831 & 0.930 & Remained \\
\hline Item 22 & 0.708 & 0.932 & Remained \\
\hline Item 23 & 0.483 & 0.935 & Remained \\
\hline Item 24 & 0.418 & 0.936 & Remained \\
\hline Item 25 & 0.739 & 0.932 & Remained \\
\hline Item 26 & 0.775 & 0.931 & Remained \\
\hline Item 27 & 0.820 & 0.931 & Remained \\
\hline Item 28 & 0.814 & 0.931 & Remained \\
\hline \multicolumn{4}{|c|}{$\begin{array}{l}27 \% \text { Sub-Upper Group Analysis: Statistical significance was observed in } 26 \text { of the } 28 \text { items }(p<0.01) \text {, while two items (Item } 3 \text { and } \\
\text { Item 12) were not statistically significant ( } p>0.05) \text {. }\end{array}$} \\
\hline \multicolumn{4}{|c|}{ Cronbach's Alpha Coefficient $=0.95$} \\
\hline \multicolumn{4}{|c|}{ Spearman-Brown Split-Half Coefficient $=0.90$} \\
\hline Guttman Spli & $=0.90$ & & \\
\hline
\end{tabular}

is suitable for use when items are scored in more than two categories.[27] Reliability coefficient varies between 0 and 1, in which values closer to 1 have higher reliability.[28] According to Nunnally (1998), the alpha reliability value must be greater than 0.70 . George and Mallery (2003) evaluated alpha value greater than 0.90 as excellent, $0.80-0.90$ as good, $0.70-0.80$ acceptable, $0.60-0.70$ moderate, $0.50-0.60$ weak, and $<0.50$ as unacceptable. [22] Cronbach's alpha coefficients for the six sub-dimensions in the colorectal cancer screening belief scale that Özsoy et al. adapted for the Turkish language and society are between 0.54-0.88.[29] In Güvenç's cervical cancer and pap smear test health belief model scale, the alpha value is between 0.62 and 0.86 for five sub-dimensions, and the alpha coefficient for cervical cancer early diagnosis scale that is Özmen's doctoral thesis is 0.89 . [30,31]

In the adaptation of Gözüm's breast cancer screening scale, Cronbach's alpha is between 0.69 and 0.83 for eight sub-dimensions. [32] Cronbach's alpha coefficient of the 24-item scale developed by the researchers is calculated as 0.95 , considered "excellent" according to the literature. Based on this value, the 24-item Attitude Scale for Cancer Screening Scale may be considered reliable.

\section{Content Validity}

Content validity refers to the extent to which the scale as a whole and each item of the scale serves the purpose of the construct.[33] The most commonly used 
Table 4. Factor loadings of the scale

\begin{tabular}{|c|c|c|}
\hline Item Number & Scale Items* & Factor Loading \\
\hline 1 & I want to undergo cancer screening at regular intervals. & 0.888 \\
\hline 2 & I want to undergo cancer screening soon. & 0.801 \\
\hline 3 & I want to receive information about cancer screening tests. & 0.865 \\
\hline \multirow[t]{2}{*}{4} & If there is anything I wonder about cancer screening, I will research it to & \\
\hline & find out. & 0.844 \\
\hline 5 & When I undergo a cancer screening test, I will follow the results. & 0.885 \\
\hline 6 & I encourage people around me to undergo cancer screening. & 0.862 \\
\hline \multirow[t]{2}{*}{7} & Giving information about cancer screenings on television, on the internet & \\
\hline & and in the newspaper has a positive effect on my screening. & 0.779 \\
\hline \multirow[t]{2}{*}{8} & Cancer screening recommendation by a health worker increases my & \\
\hline & likelihood of being screened. & 0.852 \\
\hline \multirow[t]{2}{*}{9} & If someone close to me is diagnosed with cancer, it doesn't increase the & \\
\hline & chance of undergoing cancer screening. (Reverse item) & 0.372 \\
\hline 10 & $\begin{array}{l}\text { When I undergo a cancer screening, I think that I'm doing something good } \\
\text { for myself. }\end{array}$ & 0.909 \\
\hline 11 & I only undergo cancer screening tests because I want to. & 0.627 \\
\hline \multirow[t]{2}{*}{12} & I don't want to undergo cancer screening because I'm afraid of bad & \\
\hline & test results. (Reverse item) & 0.542 \\
\hline 13 & Even if I don't have any complaints, I would undergo cancer screening. & 0.514 \\
\hline \multirow[t]{2}{*}{14} & When the center of cancer screening is too far away to go, I don't undergo & \\
\hline & screening. (Reverse item) & 0.333 \\
\hline 15 & I can't find time for to undergo cancer screening. (Reverse item) & 0.493 \\
\hline 16 & I forget to apply for cancer screening. (Reverse item) & 0.536 \\
\hline 17 & I think it's unnecessary to undergo cancer screening. (Reverse item) & 0.878 \\
\hline 18 & I think that I'm not the right age for cancer screening. (Reverse item) & 0.731 \\
\hline 19 & I'm afraid cancer screening tests will hurt me. (Reverse item) & 0.455 \\
\hline 20 & I'm concerned about the side effects of cancer screening tests. (Reverse item) & 0.399 \\
\hline 21 & I think the procedures of cancer screening are embarrassing. (Reverse item) & 0.761 \\
\hline 22 & I don't trust the results of cancer screening tests. (Reverse item) & 0.809 \\
\hline \multirow[t]{2}{*}{23} & I don't need to undergo cancer screening because I think that cancer won't & \\
\hline & happen to me. (Reverse item) & 0.857 \\
\hline 24 & I have more important things to do than cancer screening. (Reverse item) & 0.846 \\
\hline \multicolumn{3}{|c|}{ Eigenvalue $=12.66$} \\
\hline & & \\
\hline
\end{tabular}

*The scale, whose original language is Turkish, has been translated from Turkish to English by three different translators, and the translations have been combined.

method to ensure content validity is expert consultation. The expert panel is recommended to consist of $5-40$ people. $[23,24]$ It is recommended that the expert panel be composed of people who have sufficient qualifications and knowledge in the subject area, who understand the importance of the study, and are able to allocate sufficient time to the study.[24] Within the scope of this study, a panel of 17 experts was consulted to review the validity of the scale. The opinions and suggestions of each expert were carefully evaluated and some items were removed from the scale or corrected.

\section{Construct Validity}

Factor analysis is performed to determine the construct validity of the scale and the smallest factor load was 0.33 for the original form and the smallest factor load was 0.71 for the short form. It is stated in the literature that 0.30 should be accepted as the smallest factor load in factor analysis. It is recommended to exclude items below this value from the scale. $[21,23,25,26]$ The smallest factor load is 0.41 in Özsoy et al.'s colorectal cancer screening belief scale;[29] is calculated by 0.30 in Gözüm's breast cancer screening scale;[32] is found by 0.30 in Güvenç's cervical cancer and pap smear test 
Table 5. Characteristics of the attitude scale for cancer screening-short form

\begin{tabular}{|c|c|c|c|}
\hline Item Number & Scale Items* & $\begin{array}{l}\text { Item score-scale } \\
\text { score correlation }\end{array}$ & Factor loading \\
\hline 1 & I want to undergo cancer screening at regular intervals. & 0.884 & 0.902 \\
\hline 2 & I want to undergo cancer screening soon. & 0.789 & 0.818 \\
\hline 3 & I want to receive information about cancer screening tests. & 0.867 & 0.888 \\
\hline \multirow[t]{2}{*}{4} & If there is anything I wonder about cancer screening, I & & \\
\hline & will research it to find out. & 0.826 & 0.851 \\
\hline 5 & When I undergo a cancer screening test, I will follow the results. & 0.880 & 0.900 \\
\hline 6 & I encourage people around me to undergo cancer screening. & 0.850 & 0.873 \\
\hline \multirow[t]{2}{*}{7} & $\begin{array}{l}\text { Giving information about cancer screenings on television, } \\
\text { on the internet and in the newspaper has a positive effect on }\end{array}$ & & \\
\hline & my screening. & 0.773 & 0.805 \\
\hline \multirow[t]{2}{*}{8} & Cancer screening recommendation by a health worker & & \\
\hline & increases my likelihood of being screened. & 0.850 & 0.873 \\
\hline 10 & $\begin{array}{l}\text { When I undergo a cancer screening, I think that I'm doing } \\
\text { something good for myself. }\end{array}$ & 0.911 & 0.926 \\
\hline 17 & $\begin{array}{l}\text { I think it's unnecessary to undergo cancer screening. } \\
\text { (Reverse item) }\end{array}$ & 0.866 & 0.886 \\
\hline 18 & $\begin{array}{l}\text { I think that I'm not the right age for cancer screening. } \\
\text { (Reverse item) }\end{array}$ & 0.682 & 0.716 \\
\hline 21 & $\begin{array}{l}\text { I think the procedures of cancer screening are embarrassing. } \\
\text { (Reverse item) }\end{array}$ & 0.715 & 0.748 \\
\hline 22 & I don't trust the results of cancer screening tests. (Reverse item) & 0.778 & 0.806 \\
\hline 23 & $\begin{array}{l}\text { I don't need to undergo cancer screening because I think that } \\
\text { cancer won't happen to me. (Reverse item) }\end{array}$ & 0.829 & 0.852 \\
\hline 24 & $\begin{array}{l}\text { I have more important things to do than cancer screening. } \\
\text { (Reverse item) }\end{array}$ & 0.811 & 0.835 \\
\hline \multicolumn{4}{|c|}{ Cronbach's Alpha Coefficient $=0.97$} \\
\hline \multicolumn{4}{|c|}{ \%27 Sub-Upper Group Analysis= all 15 items yielded $p<0.001$} \\
\hline \multicolumn{4}{|c|}{ Spearman-Brown Split-Half Coefficient $=0.94$} \\
\hline \multicolumn{4}{|c|}{ Guttman Split-Half Coefficient $=0.94$} \\
\hline \multicolumn{4}{|c|}{ Kaiser-Meyer-Olkin (KMO) Test for Sampling Adequacy $=0.96$} \\
\hline \multicolumn{4}{|c|}{ Bartlett's Test for Sphericity: Chi-square $=5423.69 ; p<0,001$} \\
\hline \multicolumn{4}{|c|}{ Eigenvalue $=10.76$} \\
\hline Explained Variar & $c e=71.76 \%$ & & \\
\hline
\end{tabular}

*The scale, whose original language is Turkish, has been translated from Turkish to English by three different translators, and the translations have been combined.

health belief model scale [31] and is 0.36 in cervical cancer early diagnosis scale that is Özmen's doctoral thesis.[30]

It is stated in the literature that the explained variance rate of scale should be $67 \%$ at least, but it is not easy to achieve this ratio $[21,23,26]$ and when the scale consists of one dimension, it will be sufficient to have $40 \%$ variance rate. [23] In the study, the explained variance rate of the original form is $52 \%$ and that of the short form is $72 \%$. The explained variance rate is $48 \%$ in Özsoy at al's colorectal cancer screening belief scale. [29] It is 45\% in Gözüm's breast cancer screening scale,
[32] 46\% in Güvenç's cervical cancer and pap smear test health belief model scale,[31] 44\% in Özmen's cervical cancer early diagnosis scale [30] and $71 \%$ in testicular cancer screening scale.[34]

\section{Relationship between Scale Score and Gender, Edu- cation Level, and Cancer Presence Variables \\ Men scored higher than women. Women had a signifi- cantly more negative attitude towards cancer screening compared to men. Tekpinar et al. conducted a study in Antalya and reported that a higher rate of women par- ticipated in cancer screening compared to men.[14] In a}


Table 6. Results related to variables affecting scale scores

\begin{tabular}{|c|c|c|c|c|c|}
\hline $\begin{array}{l}\text { Dependent } \\
\text { variable }\end{array}$ & $\begin{array}{l}\text { Independent } \\
\text { variables }\end{array}$ & & $\begin{array}{l}\text { Mean/median } \\
\text { of the study group }\end{array}$ & Test Statistics & P-Value \\
\hline \multirow[t]{13}{*}{ Scale score } & Age & & $60.51 \pm 27.80$ & Pearson $r=0.347$ & 0.001 \\
\hline & Gender & Female & $50.71 \pm 23.05$ & $t=-6.876$ & 0.001 \\
\hline & & Male & $70.31 \pm 28.74$ & & \\
\hline & Education level & Elementary & $81.75 \pm 29.33$ & Welch $=16.092$ & 0.001 \\
\hline & & Middle school & $75.48 \pm 26.32$ & & \\
\hline & & High school & $65.24 \pm 31.48$ & & \\
\hline & & University & $54.94 \pm 25.73$ & & \\
\hline & & Master/Doctorate & $48.92 \pm 16.59$ & & \\
\hline & Smoking at any & & & & \\
\hline & period of life & Yes & $63.93 \pm 28.51$ & $t=2.710$ & 0.007 \\
\hline & & No & $55.77 \pm 26.16$ & & \\
\hline & Presence of cancer & Yes & $48.80 \pm 31.84$ & $z=-2.021$ & 0.043 \\
\hline & & No & $60.75 \pm 27.60$ & & \\
\hline
\end{tabular}

study conducted with 380 people in the 20-60 age group in Bingöl, it was reported that cancer screening rates were low in both women and men.[15] In a systematic review by Wools et al., Women were less likely to participate in screening than men.[35] There have been studies in the literature showing that screening attitudes and behaviors are higher in females than males, similar to males, and at lower rates than males. These different results can be explained by other characteristics and differences of working groups other than gender.

In this study, it was observed that the scale score decreased significantly as the education level increased. In a study conducted with a group of 380 men and women in Bingöl, there was no relationship between screening and education level.[15] In the study conducted by Tekpinar et al., it was found that those with high education level had a low desire to participate in cancer screenings. [14] One study conducted on 562 men and women in Aydin found that the illiterate group had the highest willingness to participate in cancer screening. [16] As education level increases, positive attitudes towards cancer screenings weaken. This situation can be explained by that educated people are less concerned about health, their high self-confidence levels of the education they receive, seeing themselves above health problems, incomplete and even misuse of the research and information access process brought about by education, and some and/or misinformation of some subjects that are thought to be known correctly.

Scale scores were found to be lower in participants with cancer than participants without cancer. This finding may be due to the belief that people with cancer that they will not acquire cancer again. However, there is information in the literature that multiple cancers in the same individual may occur simultaneously and in different time periods.[8] Açıkgöz et al.[17] conducted a study on women in İzmir and did not find an association between cancer presence and participation in cancer screening. Another study on 586 healthcare workers in Ankara yielded different results from our study and reported that rates of participation in cancer screening in people with cancer and/or relatives with cancer were significantly higher compared to those without cancer and/or relatives with cancer.[36]

\section{Conclusion}

As a result of this study, a new assessment instrument called the "Attitude Scale for Cancer Screening" has been developed. The scale's validity and reliability studies have been conducted. The developed scale is a fivepoint Likert-type, 24-item, one-dimensional scale. Explained variance ratio of the scale is $52.62 \%$. The scale is a valid and reliable assessment tool to measure the general attitude towards cancer screening. The scale can be used to determine the attitude towards cancer screening of male and female adult individuals between the ages of 30-70 years. The short-form version of the scale is also developed in addition to the scale's original form.

The study group, consisting of a total of 334 people, has a mean score of $60.51 \pm 27.80$ in a wide range from the minimum to the maximum score. Age, gender, education level, smoking status, and presence of cancer in the individual are determined to be variables related to scale score. 
Widespread use of the scale in the field will have many benefits. Conducting informational studies on cancer screenings in areas with low attitude and breaking the negative attitude towards screenings as well as conducting new screening studies in collaboration with Provincial Health Directorates, District Health Directorates, and early cancer diagnosis and screening centers (KETEM in Turkey) in areas with positive attitude are among a few of the benefits of measuring attitude towards cancer screening with a standard assessment tool. Since this scale may be used to identify other variables related to scale scores, it is recommended that future studies should be conducted in different locations, in different samplings, or even as multi-center studies.

Peer-review: Externally peer-reviewed.

Conflict of Interest: The authors declared that they have no conflict interests.

Ethics Committee Approval: This study is a methodological type scale-development, validity, and reliability study. The study obtains ethical approval from Necmettin Erbakan University Meram Faculty of Medicine Ethics Committee (No: 2019/1733; Date: 15.02.2019).

Financial Support: The authors declared that this study received no fund.

Authorship contributions: Concept - E.N.Y.Ö., M.U.; Design - E.N.Y.Ö., M.U., T.K.Ş.; Supervision - M.U., T.K.Ş.; Funding - None; Materials - E.N.Y.Ö., M.U., T.K.Ş.; Data collection and/or processing - E.N.Y.Ö., M.U.; Data analysis and/or interpretation - E.N.Y.Ö., M.U., T.K.Ş.; Literature search - E.N.Y.Ö., M.U., T.K.Ş.; Writing - E.N.Y.Ö., M.U., T.K.Ş.; Critical review - M.U., T.K.Ş.

\section{References}

1. WHO The Top 10 Causes of Death. Available at: http:// www.who.int/news-room/fact-sheets/detail/the-top10-causes-of-death Accessed Dec 3, 2019.

2. New Global Cancer Data: GLOBOCAN 2018. Available at: https://www.uicc.org/new-global-cancer-dataglobocan-2018 Accessed Dec 3, 2019.

3. TUİK Ölüm Nedeni İstatistikleri 2017. Available at: http://www.tuik.gov.tr/PreHaberBultenleri. do?id=27620 Accessed Dec 3, 2019.

4. T.C.Sağlık Bakanlığı Türkiye Halk Sağlığı Kurumu Bulaşıcı Olmayan Hastalıklar-Programlar ve Kanser. Available at: http://kanser.gov.tr/Dosya/Bilgi-Dokumanlari/raporlar/birim.pdf Accessed Sep 20,2019.

5. American Cancer Society Guidelines for the Early Detection of Cancer. Available at: https://www.cancer.org/healthy/find-cancer-early/cancer-screening- guidelines/american-cancer-society-guidelines-forthe-early-detection-of-cancer.html Accessed Dec 18, 2019.

6. CDC. Cancer Prevention and Control. Available at: https://www.cdc.gov/cancer/dcpc/prevention/screening.htm Accessed Dec 18, 2019.

7. National Cancer Institute. Cancer Screening Tests. Available at: https:/www.cancer.gov/about-cancer/ screening/screening-tests Accessed Dec 18, 2019.

8. Jameson JL, Fauci AS, Kasper DL, Hauser SL, Longo DL, Loscalzo J. Harrison's Principles of Internal Medicine. 20th ed. Canada, USA: Mc Graw Hill Education; 2018.

9. Detels R, Gulliford M, Karim AQ, Tan CC. Oxford Textbook of Global Public Health. 6th Edition. New York, USA: Oxford University Press; 2015.

10. Stewart BW, Wild CP. World Cancer Report 2014. Lyon, France: IARC Publications; 2014.

11. T.C. Sağlık Bakanlığı Halk Sağlığı Genel Müdürlüğü. Kanser Taramaları. Available at: https://hsgm.saglik. gov.tr/tr/kanser-taramalari Accessed Dec 28, 2019.

12. Tezcan SG. Temel Epidemiyoloji. Ankara, Türkiye: Hipokrat Kitapevi; 2017.

13. Tavşancıl E. Tutumların Ölçülmesi ve SPSS ile Veri Analizi. Ankara, Türkiye: Nobel Yayınları; 2019.

14. Tekpınar H, Aşık Z, Özen M. Aile Hekimliği polikliniğine başvuran hastaların kanser taramalarına ilişkin yaklaşımlarının değerlendirilmesi. Türkiye Aile Hekimliği Dergisi 2018;22(1):28-36.

15. Yiğitbaş Ç, Bulut A, Bulut A, Semerci M. Knowledge and attitudes about cancer screening tests on adult admitted to state hospital of bingol. Türk Jinekolojik Onkoloji Dergisi 2016;19(2):29-38.

16. Şahin NŞ, Üner BA, Aydın M, Akçan A, Gemalmaz A, Dişçigil G, et al. Aydın Merkez İlçede Kolorektal Kanser Taramasına İlişkin Bilgi, Tutum ve Engeller. Türkiye Aile Hekimliği Dergisi 2015;19(1):37-48.

17. Açıkgöz A, Çehreli R, Ellidokuz H. Women's knowledge and attitude about cancer and thr behaviour for early diagnosis procedures. DEÜ Tip Fakültesi Dergisi 2011;25(3):145-54.

18. Sümbüloğlu V, Sümbüloğlu K. Klinik ve Saha Araştırmalarında Örnekleme Yöntemleri ve Örneklem Büyüklüğü. Ankara, Türkiye: Hatiboğlu Yayınevi; 2005.

19. Seçer İ. Psikolojik Test Geliştirme ve Uyarlama Süreci; SPSS ve Lisrel Uygulamaları. 1st ed. Ankara, Türkiye: Anı Yayıncilık; 2015.

20. Tezbaşaran AA. Likert Tipi Ölçek Hazırlama Kılavuzu. 3. Sürüm. Mersin, Türkiye; 2008.

21. Özdamar K. Ölçek ve Test Geliştirme Yapısal Eşitlik Modellemesi. 2nd ed. Eskişehir, Türkiye: Nisan Kitabevi; 2016.

22. Şencan H. Sosyal ve Davranışsal Ölçümlerde Güvenilirlik ve Geçerlilik. 1st ed. Ankara, Türkiye: Seçkin Yayıncılık; 2005. 
23. Alpar R. Spor, Sağlık ve Eğitim Bilimlerinden Örneklerle Uygulamalı İstatistik ve Geçerlik-Güvenirlik. 3rd ed. Ankara, Türkiye: Detay Yayıncılık; 2014.

24. Yurdugül H. Ölçek geliştirme çalışmalarında kapsam geçerliği için kapsam geçerlik indekslerinin kullanılmass. In: Proceedings of the XIV. Ulusal Eğitim Bilimleri Kongresi. Denizli: 2005.

25. Field A. Discovering statistics using SPSS. 3rd ed. London, England: SAGE Publications; 2009.

26. Büyüköztürk Ş. Factor Analysis: Basic Concepts and Using to Development Scale 2002;32(32):470-83.

27. Ercan İ, Kan İ. Reliability and Validity in The Scales. Uludağ Üniversitesi Tip Fakültesi Dergisi 2004;30(3):211-6.

28. Aksakoğlu G. Sağlikta araştırma ve çözümleme. 3rd ed. İzmir, Türkiye: Dokuz Eylül Üniversitesi Rektörlük Basımevi; 2013.

29. Ozsoy SA, Ardahan M, Ozmen D. Reliability and validity of the colorectal cancer screening belief scale in Turkey. Cancer Nurs 2007;30(2):139-45.

30. Özmen D, Altuğ Özsoy S. Sağlık inanç modeli yaklaşımı ile servikal kanserin erken tanısına yönelik ölçel çalışması. Doktora, Ege Üniversitesi Sağlık Bilimleri Enstitüsü, İzmir, Türkiye: 2004.

31. Guvenc G, Akyuz A, Açikel CH. Health Belief Model Scale for Cervical Cancer and Pap Smear Test: psychometric testing. J Adv Nurs 2011;67(2):428-37.

32. Gözüm S, Karayurt Ö, Aydın İ. The results of turkish adaptations of champion's health belief model scale at breast cancer screening. Hemşirelikte Araştırma Geliştirme Dergisi 2004:1;71-85.

33.Karakoç FY, Dönmez L. Basic Principles of Scale Development. Tip Eğitimi Dünyası 2014;40:39-49.

34. Pınar G, Öksüz E, Beder A, Özhan Elbaş N. Reliability and validity of the Turkish adaptation of the Champion's health belief model scale at testicular cancer screening. Tip Araştırmaları Dergisi 2011;9(2):89-96.

35. Wools A, Dapper EA, de Leeuw JR. Colorectal cancer screening participation: a systematic review. Eur J Public Health 2016;26(1):158-68.

36.Kaya C, Üstü Y, Özyörük E, Aydemir Ö, Şimşek Ç, Şahin AD. Knowledge, Attitudes and Behaviors of Health Workers About Cancer Screenings. Ankara Med J 2017;17(1):73-83. 